\title{
Lyophilized Powder for Extended Release Injectable Suspension Dosage Form
}

National Cancer Institute

\section{Source}

National Cancer Institute. Lyophilized Powder for Extended Release Injectable Suspension

Dosage Form. NCI Thesaurus. Code C42956.

A freeze dried powder intended for injection following reconstitution with a suitable solvent to form a suspension that is designed to release active and/or inert ing redient(s) at a controlled, prolonged rate so as to reduce dosing frequency. 